\title{
Spain and Catalonia, rebuilding a Pact
}

[partial translation from the original editorial in Spanish; translated chapters: 1 , Introduction; 4, Analysis of the current scenarios and 5, Final Thoughts: a proposal for a new constitutional pact to rebuild a relationship between Catalonia and the whole of Spain]

Abstract: In this editorial commentary, we want to express our opinion and propose the construction of an inclusive discourse. So we try to explain the historical and legal processes in their complexity and its internal reasons, presenting the different positions to understand them with honesty. We believe that this can be a service to our readers.

First addressed two perspectives on the Catalan issue: the historical and the legal question. From both came to a first conclusion: neither the history nor the right can resolve an issue that, over time, has not done anything else but get complicated, especially in recent years, although both perspectives offer some light, because they provide keys to understanding. We are really convinced that neither serve on their own to resolve the issue. Only a political Pact can guide and facilitate a stable solution. After all, articulate a political Pact is also the result of a history and is ordered legally, but exceeds both perspectives as requires capacity and will of create then conditions for found a new relationship between Spain and Catalonia.

Then we make our explicit proposal: to advance in a new resolution on the Catalan issue we need, as a complex and plural society, rebuild a new relationship and to found a new political Pact from social and cultural consensus of pre-political character (i.e. emotional, moral-axiological and ideological) serving as to base for the political Pact, both among the citizens of Catalonia and between them and the citizens of the whole of Spain.

In the perspective of a strong, united, coherent and stable Europe in which federal asymmetries should not hinder progress in a growing unit, we could also think a Spain able to integrate the common which is different. Solidarity and equality among all Spanish citizens must include recognition of the differential, the plural and diverse Spain from marriage that is expressed through the federal Pact.

\footnotetext{
\begin{tabular}{c} 
España y Cataluña: la reconstrucción de un pacto - v5-jmm - edito RFS 71 (2016/1) no 281· 14 de septiembre de \\
Página 1 201611:25 \\
\hline
\end{tabular}
} 
The recognition of the singularity is accomplished only and necessarily by the bilateralism in the relations, which is only one possible formula among others. We therefore propose a new political Pact between the citizens, who arrived the day, it can be subjected to a referendum on constitutional revision involving all Spaniards. This Pact will be possible if all we reach an inclusive discourse. It is our proposal.

\section{L'Espagne et la Catalogne: la reconstruction d'un pacte}

Résumé: Dans cet éditorial nous voulons nous prononcer et proposer la construction d'un discours inclusif. Pour cela, nous essayons d'expliquer les processus historiques et juridiques dans leur complexité et leurs raisons internes, en présentant avec honnêteté les différentes positions et ainsi, essayer de les comprendre. Nous pensons que cela peut rendre service à nos lecteurs.

D'abord nous abordons la problématique catalane depuis deux perspectives: la perspective historique et la perspective juridique. À partir de cela, nous arrivons à une première conclusion: ni l'histoire ni le droit peuvent résoudre une problématique qui, avec le temps, n'a fait que se compliquer, surtout dans les dernières années. Malgré cela, les deux perspectives nous apportent un peu de lumière sur la question, surtout au niveau de la compréhension. Nous sommes réellement convaincus que ni l'une ni l'autre servent d'elles mêmes à résoudre le problème. Seul un pacte politique peut orienter et permettre une solution stable. Tout compte fait, articuler un pacte politique est aussi le résultat d'une histoire et s'organise juridiquement, tout en dépassant les deux perspectives, puisqu'il requiert d'une capacité et d'une volonté de créer les conditions pour fonder une nouvelle relation entre l'Espagne et la Catalogne.

Ensuite nous faisons notre proposition explicitement: pour avancer dans une nouvelle résolution sur la problématique catalane, il nous faut, en tant que société complexe et pluraliste, reconstruire une nouvelle relation et fonder un nouveau pacte politique à partir d'un consensus social et culturel de caractère pré-politique (c'est-à-dire, émotionnel, moral-axiologique et idéologique). Ce consensus sera la base du pacte politique, aussi bien entre les citoyens de la Catalogne qu'entre ces derniers et les citoyens de l'ensemble de l'Espagne.

Dans la perspective d'une Europe forte, unie, cohérente et stable, dans laquelle les asymétries fédérales ne doivent pas empêcher d'avancer vers une unité de plus en plus grande, nous pouvons également penser la possibilité d'une Espagne capable d'intégrer ce qui est commun et ce qui est différent. La solidarité et l'égalité entre tous les citoyens espagnols doivent inclure la reconnaissance de la différence, de I'Espagne pluraliste et diverse, articulée à partir de l'union exprimée à travers un pacte fédéral. 
La reconnaissance de la singularité ne dépend pas seulement et nécessairement de la bilatéralité, qui n'est qu'une formule possible parmi d'autres. Nous proposons donc un nouveau pacte politique entre citoyens qui, le moment venu, puisse être soumis à un référendum de révision constitutionnelle et dans lequel pourrons participer tous les citoyens espagnols. Ce pacte sera possible si, entre tous, nous trouvons un discours inclusif. C'est notre proposition.

Key words:

Mots clé:

Date of acceptance: 21 April, 2016

Diverses són les parles i diversos els homes, i convindran molts noms a un sol amor (Salvador Espriu) (Quote in Catalan: "Diverse is the talk and diverse is the man, and many names will agree that there is only one love.") ${ }^{1}$.

Within the current situation facing Europe, everything that unites: strengthens and all that divides: weakens. And Europe needs strength, unity and coherence more than ever. As partners and neighbors, we want a strong and stable Spain (Manuel Valls, Prime Minister of France) ${ }^{2}$.

"I would like to warn the gentlemen of the City [...that] unless they embrace wisdom in good time, the system upon which they live will work so very ill that they will be overwhelmed by irresistible things which they will hate much more than the mild and limited remedies offered them now..." (John M. Keynes) ${ }^{3}$.

\section{Introduction ${ }^{4}$}

The maturity and strength of a society is reflected in its ability to address critical problems, knowing how to accurately detect, define, and then rank them and

\footnotetext{
${ }^{4}$ The editorial, as always, is the result of reflection and dialogue among members of the Editorial Board that was developed in the following working sessions: 20-01-2016, 11-02-2016, 9-03-2016, and 19-04-2016, and only binds the Council. In this case there was no involvement of any external speaker.
}

\begin{tabular}{c} 
España y Cataluña: la reconstrucción de un pacto - v5-jmm - edito RFS 71 (2016/1) no 281· 14 de septiembre de \\
Página 3 201611:25 \\
\hline
\end{tabular}


prioritize those that are most important and urgent. From this point on, one can undertake a solution.

There seems to be a problem, which in this text is conventionally referred to as the Catalan Question, which essentially affects the coexistence and political dynamics not only in Catalonia but also in Spain as a whole. ${ }^{5}$ At this time, the question seems important though it is neither the only, nor the most decisive. In our world there are undoubtedly a number of problems to prioritize: the terrorist violence that fully affects Europe, climate change and the green or ecological crisis, refugees from the Mediterranean, but above all poverty and growing inequalities, both the global ones as well as internal ones found in every society, all in turn generating more poverty. These, at least, are essential issues which we cannot easily stay aloof to, they are enormously complex and require a great collective effort. Besides these issues, the Catalan question does not seem to be among the most decisive for our world.

Turning our gaze to the more immediate context, we could say that in Spain today could stress at least four large blocks of questions or concerns to prioritize and resolve: the reinforcement of Europeanism as the key to solving the crisis, although the current European scenario is also part of the crisis, and through this perspective, the consolidation of the social market economy (Soziale Marktwirtschaft) established by the Treaty of Lisbon; ${ }^{6}$ an economic recovery that will guarantee stability and growth, but is certainly oriented decisively at the social integration of excluded and young people, a genuine and realistic interregional solidarity and the development of social public policies consistent with the needs of the majority of

\footnotetext{
${ }^{5}$ In this commentary, we are aware that terminology can sometimes be vacillating and can be ambiguous, we will use the terms Catalonia and Spain as follows: Catalonia serves both to designate a geographic region as well as an autonomous region that is part of the administrative level of Spain and, as such, has a precise constitutional legal configuration. Moreover, Catalonia is also a national community with a strong historical personality that has certainly been shaped throughout its history in different ways from a legal and institutional standpoint and its relationship with the whole Iberian space. Spain, namely the Kingdom of Spain, is a country, a nation, a sovereign state, a full member of the community of states, a member of the UN and the European Union. Catalonia understands it to be a historical and institutional subject and as a community, part of Spain. This use does not distort, in our view, the possible range of formulas related to Catalonia, part of Spain, with Spain as a state in which there are 17 communities and two autonomous cities and is part of the European Union, currently integrated among the 28 states. We are not putting Catalonia up against Spain as if one excluded the other like different political subjects, yet we are not presupposing a unique formula for the relationship between Catalonia and Spain, which we sometimes refer to as the rest of Spain or the whole of Spain.

${ }^{6}$ Cited from our editorial: "Un sistema de Economía social de mercado para una Europa solidaria, responsable y productiva" (A social market economy for a supportive, responsible and productive Europe): RFS 67 (2012) 5-29.
}

España y Cataluña: la reconstrucción de un pacto - v5-jmm - edito RFS 71 (2016/1) no 281· 14 de septiembre de
201611:25


population and a fair understanding of the common good..$^{7}$ Democratic regeneration, the fight against systemic corruption, and the promotion of a genuine social and political pact that the whole system guarantees has allowed us to enjoy a period of peace, ${ }^{8}$ unprecedented prosperity, and human and social development in our contemporary times. ${ }^{9}$ Lastly, there is the Catalan Question, to which we devote this editorial.

Why, then, do we believe is that question important? Catalonia's troubled relationship with the whole of Spain is not a new issue. At least since the second half of the nineteenth century the Catalan Question has been raised at the center of the social, political, and institutional Spanish table. As we have recently proven, the existing political dynamics in the Spanish space and the Catalan space are often interdependently conditioned, in a way that we might call them structural or persistent.

On the one hand, the economy intrinsically links both spaces: in 2013 , for example, Catalonia sold goods and services to the rest of Spain equaling 44 billion Euros, 30\% of its production, more than what was sold outside Spain; and vice versa, in the Catalan market, goods and services consumed were a total of 25.5 billion Euros which came from other Spanish regions; the trade surplus between Catalonia and the rest of Spain is 18.5 billion Euros and the trade deficit of Catalonia abroad is 16.5 billion Euros. In fact, Catalonia is by far the region with a higher positive balance regarding interregional trade.

On the other hand, coexistence and popular and family ties between citizens of Catalonia and other Spanish regions are strong or very strong. Catalonia had 7,565,603 inhabitants at the time of the 2012 census, after years of continued growth mainly because of foreign immigration. Since 2001, there has been an increase in population of one million people, a fact which places Catalonia above the Spanish and European average in welcoming foreigners. The population increase

\footnotetext{
${ }^{7}$ Cited from our editorial: "Política económica del Gobierno de España 2011-2015. Estabilidad lograda, fractura persistente" (Economic policy of the Government of Spain from 2011 to 2015. Stability achieved, persistent fracture): RFS 70 (2015) 373-396.

${ }^{8}$ With the exception of terrorism by the GRAPO and ETA, finally defeated by the rule of law.

9 Cited from our editorials: "Regeneración ética y compromiso político para una sociedad democrática avanzada" (Ethical regeneration and political commitment to an advanced democratic society): RFS 68 (2013) 5-20, and "Crisis económica y derechos sociales irreductibles. Valor de la dignidad humana como criterio para los derechos sociales" (Economic Crisis and irreducible social rights. Value of human dignity as a criterion for social rights): RFS 68 (2013) 179-201.
}

España y Cataluña: la reconstrucción de un pacto - v5-jmm - edito RFS 71 (2016/1) no 281· 14 de septiembre de
201611:25


corresponds to the nearly one million foreigners currently living in Catalonia (18\% of the population). The migration impact has been particularly relevant in the metropolitan area of Barcelona, an area of about five million people that makes up more than $67 \%$ of the population of Catalonia. The last major wave of immigration occurred between 1950 and 1975, when the population grew by nearly two and half million people from all over Spain. Currently $64 \%$ of Catalans were born in Catalonia $(4,830,000 \text { - } 2015 \text { data })^{10}, 20 \%$ were born in other communities of Spain (Andalusia 619,000 or 273,000 in both Castillas, including Madrid) and about $15 \%$ are foreign, an immigrant from the EU or other areas. Moreover, 242,000 Catalonia-born people live outside of Spain (including about 80,000 in the EU according to data from 2015, although only six years earlier they were 144,000 ). Only $25 \%$ of the Catalan population have four grandparents born in Catalonia, which is to say that $75 \%$ of its population is of more recent immigrant origin or the two great migratory waves of the twentieth century (from the 20s and 50s and later); we can say with some certainty that most Catalan families have their roots wholly or partially in other regions of Spain, which would help to understand why Garcia, Martinez, Lopez, Sanchez, Rodriguez, Fernandez Perez, Gonzalez, Gomez and Ruiz are currently the ten most common surnames in Catalonia.

We do not come from such different and distant cultures ${ }^{11}$, therefore we must recognize that Catalonia is among the most complex and pluralistic societies of our euro-western area, a society of miscegenation and complex identities. This will always be key to approaching the Catalan Question.

Therefore, there are four reasons that make the Catalan question a Spanish central issue as well: the institutional policy, pluralist dynamics of confrontation, the trade balance - and the economy in general- and, finally, the structure and demographic dynamics. When the Catalan Question becomes problematic, or when it is discussed, it is always a central issue for Spain.

This editorial's intentions are twofold. Apparently everything or almost everything has already been said. What we really need is to rule dispassionately and generate

\footnotetext{
${ }^{10}$ That percentage for the whole of Spain stood at $86.8 \%$. This difference explains one of the demographic and sociological characteristics that makes Catalonia a society with a strong "mestizo" (mixed-race) component.

${ }^{11}$ Great Hispanists, and historians on Catalonia, from the twentieth century such as Jaume Vicens Vives, Miquel Batllori, Martin de Riquer, John H. Elliott or Pierre Vilar repeated that you cannot understand Catalan culture without the Spanish one, nor this without that.
}

\begin{tabular}{c|c} 
España y Cataluña: la reconstrucción de un pacto - v5-jmm - edito RFS $71(2016 / 1)$ no $281 \cdot 14$ de septiembre de \\
201611:25
\end{tabular}


an inclusive discourse. On the one hand, we will try to breakdown the "evidence" that exists in some areas, explaining the historical, legal, and political processes in their complexity, within the possibilities of space and the editorial genre. On the other hand, being aware of being subject to part of the process, we will try to explain the internal reasons for them, honestly seeking to present the different positions in order to understand them. We believe that this way we will gain in the quality of intellection or understanding, even if we lose some objectivity, which, on the other hand, will reside at only an apparent, though unlikely, misleading and inadequate analytical distance.

In this editorial, we approach the Catalan question from two valuable but insufficient perspectives: the historical (Part Two) and legal (Part Three), perspectives from which we will reach a first conclusion: neither history nor the law can, themselves, settle a question that over time has been shaped in such a way that only a political agreement can guide and enable a solution. We affirm that both the historical and the legal perspective provide the key to understanding and therefore we focus on them, but we are also convinced that neither serve to resolve the issue, but without them it is not possible to articulate a political pact like the one we propose, which ultimately is the result of history and legally mandated, but always exceeds both perspectives.

In fact, the historical perspective, in addition to its complexity, faces old and very recent processes of "nationalization" of history in every community, whether of conservative-populist, National-Catholic or liberal-progressive attempts to "nationalize" Spanish history, or the romantic-medieval, popular-Catholic, or Republican attempts to "nationalize" Catalan history.

Nor do we want to relativize nor downplay the value of the law. On the contrary, we know that legal guaranteeism is an essential part of democracy, but we are wary of any attempt to entrust the power of the law with the possibility of resolving a political and cultural problem that is so complex.

In the fourth part, we will propose some current scenarios and from there, in the fifth part, we will make our proposal clear. To progress with a new resolution on the Catalan question we need, as a complex and pluralistic society, to rebuild a new 
relationship that integrates two narratives, articulating the differential in common and developing the general and common through recognition of singularity. We can reach a new pact based on a social and cultural consensus with a pre-political character that substantiates and accompanies this proposal. It would be a pact both among the citizens of Catalonia, and between them and the citizens of the whole of Spain, a pact that will permit a political agreement subject to a referendum of constitutional review where all Spanish citizens participate and, among them, obviously the citizens of Catalonia. This would be a new constitutional pact among all Spaniards and between Spain and Catalonia, which corresponds to everyone because everyone is affected.

\section{Analysis of the current scenarios}

At present, Spring of 2016, we believe we can detect three possibilities or scenarios, based on different analyses of reality and different attitudes with quite a lot of support from each: institutional rigidity and dogmatic, mind stagnation; emotional heresy and forward flight; and proposing clear positions on dialogue, negotiation and the reaching of agreements. The presentation of these three keys will allow us to move from the last part to a purposeful conclusion that we consider reasonable.

\subsection{First scenario: institutional rigidity and mental stagnation}

Institutional rigidity, although a legally impeccable position, is unrealistic not to attend at all to a social outcry for change in Catalonia, regardless of whether or not this outcry responds to a majority of the population. In the regional elections of 27 September, $2015,47 \%$ of the electorate voted for independence parties, against $53 \%$ who did not; but within this $53 \%$ there would be a significant part who would favor a referendum only in Catalonia to exercise the "right to decide". The percentages in the whole of Spanish society are obviously very different, with an overwhelming majority against the secession of Catalonia. At the time, the rejection by the Spanish Congress of Deputies of the Parliament of Catalonia's request to call a referendum on independence was the following: 299 deputies against and only 47 deputies in favor. At the time, most of the Catalan deputies who voted against were from the socialist and popular parties. For the reasons we have discussed extensively in the third part of this editorial, we think that this is not a solution that will allow us to seek and find solutions to the Catalan Question. Spain has a problem of integration because part of the population feels mistreated and left out, and on the other hand, 
the same constitutional institution is questioned. We do not want to repeat the arguments presented, just bring them to mind. ${ }^{12}$

The rigidity of the conflicting parties, the secessionist unilateralism and threats of disobedience and split ("disconnection") that are answered from the legal formalism and mental stagnation, only feed dialectical tension and spirals of verbal, institutional, and emotional violence. As has so often been said, there are "separatists" because there are "separators" and vice versa. The legal firm, institutional clarity, consistency, and constitutional loyalty of some are not incompatible with the ability to listen to proposals and offer partial negotiations. And above all, a better job of political education is possible, in search of the true reasons of consensus.

\subsection{Second stage: emotional heresy and forward flight}

Progress towards a unilateral secessionist insurrection, disobedience, fait accompli such as the so-called "embassies" or "exclusive" agencies of social security or tax authorities (the others already exist and are fully legal and functional), legal breaches, and ultimately the constitutional process designed for many are shaping a vision of Catalonia far from the Catalan social reality, much richer, more complex and varied than this dominant image, this mental framework.

The current independence strategy is weak but stubborn and skilful: it can be strengthened like a phoenix! The independence movement is weak, but is not exhausted. On the other hand, together with the two main players, the two nationalist bourgeoisies that make up the "extractive elites" own the media and financial power in the political power environment. It is necessary to acknowledge the strength of Catalan independence nationalism from the lower middle-class, and in that sense, a Republican and mesocratic popular nationalism (bourgeois or minstrel), with a strong presence from the last third of the nineteenth century, which

\footnotetext{
${ }^{12}$ The disproportionate use that large media sectors, especially in the capital, have done with Article 155 of the EC is unwarranted. This is no "suspension of autonomy", as they say abusively, but implementation of legislation guaranteeing the autonomous State. In the event there was an attack on the "general interest" and the "protection of the rights of citizenship" were necessary, the application would compel talks between the Spanish government and the Catalan government, but neither is the imprisonment of a government or president thinkable, nor the dissolution of an institution. The president of the Government is the highest representation of the State in Catalonia. In the minds of the constituents, the image of October 1934 in the Plaza de Sant Jaume was perhaps very present as well as that of the Catalan government at the time between the iron jail bars of Puerto de Santa María until the elections in February 1936. This would be an example of how you can -or not- use the law in an exclusive and aggressive manner, like in "last resort". Cited. J A. González CASANOVA (2014) op. cit., 164-166, 117-119
}

España y Cataluña: la reconstrucción de un pacto - v5-jmm - edito RFS 71 (2016/1) no 281· 14 de septiembre de
201611:25


has hegemonized nationalism in some periods, particularly in the cycle of the second Republic (1931-1939) and in recent years (2003-2015). We cannot overlook the historical and current weight of separatism, which is not just artificially fed from power, money, corruption, patronage, etc. nor from the legalistic rigidity of central governments and the financial hegemonic bloc which controls the central power. There is also a profound stiffness ("emotional heresy") that has permeated many sectors, especially in Catalonia ("they don't want us" and "we have nothing to expect from Madrid / Spain").

Scenarios 4.1 and 4.2 should be kept in mind, they feed off each other, and that some positions, apparently balanced between extremes, help strengthen extremisms by contaminating some negotiating proposals rather than requiring lucid and historical insight. There are indefinite positions that contribute to the consolidation of the rupture strategy by insisting on the "rhetoric" of dialogue or opportunistic vagueness and an indefinite delay of processes without making decisions or making them incoherently.

4.3. Third scenario: negotiating positions with the clarity and firmness of the constitutional democratic principles, but with equal flexibility and moderation

In times of uncertainty and indignation, it is not advisable to make hasty decisions, yet we must use the wisdom proposed by Keynes, whom we quoted in the exergue. Addressing the London financial elites, he warned them of the risk of making the system ill unless they embraced wisdom in time. ${ }^{13}$

Sometimes are there not too many "emergencies"? Should we not learn the profound wisdom that the following words contain: the whole is more than the part, time is more than space?

Political actors and civil society must be able to find that lucidity and make that historic discernment that causes slow but steady and sound processes that propel us on the right track.

Before it is possible to support the political sentiments of the towns -and we feel that at this juncture it is not possible- we can move forward with a commitment to

${ }^{13}$ J. M. KEYNES (1931) The Collected Writings of John Maynard Keynes. Cited.

\begin{tabular}{l|c} 
Página & $\begin{array}{c}\text { España y Cataluña: la reconstrucción de un pacto - v5-jmm - edito RFS } 71(2016 / 1) \text { no } 281 \cdot 14 \text { de septiembre de } \\
10\end{array}$ \\
\hline
\end{tabular}


transitional agreements, which at some point, can mature into more stable and deeply shared pacts. First we have to achieve the unblocking of the situation and for that, we speak of what happened, accept the perplexity without delegitimizing conflicting emotions, recognize that we did not anticipate the facts nor the times. The current entrenchment is not good for anyone, for any political actor. Although it is not obvious to everyone that if we all accept some minor losses, we can all achieve important success, this seems to be the best bet to us.

It is true that at another time this magazine was in favor of a deliberative democracy ${ }^{14}$, political wisdom should make us accept that during these times, we can aspire only to proposing a model of aggregative interests. The "aggregate model" theorized at the time by Joseph A. Schumpeter ${ }^{15}$, appeared to have been overcome by the deliberative model. The interested addition of preferences through political parties, representatives for whom we could vote for from time to time no longer sufficed us. This proposal of democracy as "aggregation" makes us understand it not only as a system that rationally creates a discussion and a proposal apart from the recognized communication of equal partners (deliberative democracy according to Habermas and Rawls), but as a system that alternately accepts or rejects some leaders through competitive elections.

In our time it seems we cannot expect an immediate construction of shared objectives with values that have common meanings for all political actors. We are faced with the choice between strengthening parliamentary consensus on the constitutional and European integration project or slip and bet on a model of agonistic pluralism ${ }^{16}$. Faced with this dilemma, we are inclined to move slowly, following a democratic model of aggregation of interests, to arrive at some point to the critical cooperative democratic model ${ }^{17}$.

One thing is to propose and defend an ideal and another is to recognize that in a given situation, it may be better to reach practical compromises that add individual and corporate interests and are negotiated from the clarity and precision of the different positions of each political actor. Habermas once said, that in order for there

\footnotetext{
${ }^{14}$ RFS 70 (2015) 18-19.

${ }^{15}$ Capitalism, Socialism and Democracy, New York 1947.

16 Qutoe: Ch. Mouffe (2016) The democratic paradox. The danger of consensus in contemporary politics, [The Democratic Paradox, 2000] Barcelona, Gedisa.

${ }^{17}$ RFS 70 (2015) 19-21.
} 
to be a genuine consensus, certain ideal situations for dialogue and discussion are needed. We think that in today's Spain these circumstances do not exist. The European context of crisis is not able to rely on a stable and stimulating framework. The European political pact based on some civic values such as solidarity, the defense of pluralism, the common good or other public virtues is overstretched. We have to contribute to its regeneration.

Although we continue to believe that the realm of the pre-political (moral, cultural, anthropological-social and spiritual) is the area that continues to provide and bury efforts, today we want to immediately emphasize that by just appealing to interest and need, we can reach agreements that allow us to unblock the situation.

This third scenario, the least worse for us, should combine pragmatic realism from an aggregative conception of democracy ("win-win") with the clarity of the principles, flexibility and foresight in management and transparency in all processes, loyally agreed and accepted by all parties.

\section{Final Thoughts: a proposal for a new constitutional pact to rebuild a relationship between Catalonia and the whole of Spain}

A new pact should be produced in Catalonia, as well as between Catalonia and Spain; a renewed pact among Catalans, between them and all Spaniards, responding to an intelligent search and discerned consensus. It is, in short, a new pact that gives way to nationalist hegemony in the media, in mass mobilization and the proactive initiative, the positions of the constitutionalist parties to the pact.

The centerpiece of this stage, to achieve ratification in a political referendum held in Spain and therefore in Catalonia, would be a constitutional revision to build a better funded and more robust federal unitary pact (foedus) than the previous. ${ }^{18}$

In a previous editorial, our magazine proposed "a deliberative, substantial democracy, with constitutionalized guarantees, according to our best European

\footnotetext{
${ }^{18}$ Some constitutional provisions from 1978 (additional 1 on leasehold historical rights; transient 2 on the territories that once "plebiscited" a Statute of autonomy and they found themselves in a situation of different starting points, and transient 4, where they expected the possible confluence of two territories with different origins and legitimacies) could serve to support a constitutional review of the federalist court, which however, would be more desirable than expressly appearing in the provisions of the revised Constitution to give it a solid foundation.
}

Página España y Cataluña: la reconstrucción de un pacto - v5-jmm - edito RFS 71 (2016/1) no 281· 14 de septiembre de 
tradition."19 Facing the so-called emotional or competitive fluid democracies and aggregative or competitive interested democracies, democracy at the service of the common good fosters a culture of stability and accord to service, especially the common interests of society.

The democratic project must articulate the social complexity of the responses to the deliberative participation of the people, against the kidnapping of the problems by elites or the populists' using the system to their advantage. At the root of this democratic system, deliberative in its forms and cooperative in its ways, factors ought to be complementary where they express both the force of law and the affirmation of the growing need for a culture of partnership and civic friendship, making it sustainable and allowing for its continuous foundation. This culture of partnership and reciprocity references the Aristotelian conception of civic friendship developed in the Nicomachean Ethics ${ }^{20}$. Societies need to survive and thrive, a good without public life does not work: civic friendship

citizens of a State that belong to it, know they have to pursue common goals and that there is already a bond that unites them and leads them to try to achieve these objectives, provided that legitimate differences are respected and where there are no comparative grievances. ${ }^{21}$

"Give space" to others, to other citizens with whom projects and goals of citizenship are shared, adopt the asceticism of the remaining time, the wait for the necessary efforts to achieve and maintain the project, cultivate and expand communion spaces day by day. These should be characteristic signs of a deliberative and civic democracy where recognition, proximity, and reciprocity fit, in a way that civic friendship is politically maintained.

This mission is not only that of the rulers. Caring for democracy should not be entrusted only to the elites who are better prepared or willing, but a population prepared to deepen an advanced democracy. To do this we must recover, develop and share common projects on which we can deliberate and that, as a people, can summon us. General education, research and reflection in particular, self-awareness of the important social responsibility of political parties and each of its components,

\footnotetext{
${ }^{19}$ Cited. "La democracia al servicio de todos, integrante del bien común" (Democracy at the service of everyone, part of the common good): RFS 70 (2015) 7-28.

${ }^{20}$ Books VIII and IX.

${ }^{21}$ A. CoRtina (2008) “Amistad cívica” (Civic Friendship), in El País, 6-V-2008.
}

\begin{tabular}{l|l}
$\begin{array}{l}\text { Página } \\
13\end{array}$ & $\begin{array}{c}\text { España y Cataluña: la reconstrucción de un pacto - v5-jmm - edito RFS 71 (2016/1) no 281· 14 de septiembre de } \\
201611: 25\end{array}$ \\
\hline
\end{tabular}


the media and journalists, social movements and their leaders and a specific civic education, these are essential means for democratic regeneration.

As noted above, the first part of this transition to overcome the deadlocked positions is negotiation; in a second stage, it will give way to the search and obtaining of a new possible pact to respond to the great challenge before us: to articulate the common with the differential. This is the great challenge, no doubt about it. What is common is good for everyone, so singular makes us stronger, united, stable and consistent in a Europe subject to global challenges and a strong institutional crisis and integrating project $^{22}$.

\subsection{We build: a process to agree on shared political aims}

You learn to deliberate by deliberating. This deliberation is what leads to a renewed realization of the true "right to decide", deliberative and constructive social selfdetermination of citizenship with the following characteristics:

1. It is time for a new pact. This will be possible if we rebuild a shared cultural fabric and are able to formulate critical cooperative political objectives. For that, all social, media, economic, university and cultural actors, including religious denominations, obviously including the Catholic Church (as we understand, plays a major role) must build trust. For this, many actors must engage in this great project: build trust in the plural Hispanic area. This is a great time for civil society as it can promote areas of listening and development of shared narratives. We have a common history and several unique and valuable stories that are the heritage of all. We have to convince ourselves of this. We have to be able to tell these stories together, together we can rewrite the common history of Spain by way of Europe after the Second World War, and the history of each of its regions (historical nationalities, nationalities, regions, etc.).

2. You learn how to reach an agreement by agreeing and telling the story of agreements that runs through the history of Catalonia and Spain. We were not born without many sacrifices, but with many ideals, but also with large doses of realism and pragmatic idealism. Recent European history also teaches that what unites us is

\footnotetext{
${ }^{22}$ At the time of this writing, two months before the British referendum. The event and the impact thereof on the European integration project will have its own upcoming editorial comment in 2016.
} 
better than what divides us, that time is superior to space. Pope Francis has repeated this theological principle, which is also philosophical and social, often along with other principles. It may not be amiss to remember, however briefly: affirmation that time is greater than space, allowing us to work long term without obsessing over immediate results, starting processes entrusting that time illuminates and transforms the links of a chain that is constantly growing, with no return. Second, unity prevails over conflict; third, reality is more important than the idea; and fourth, which especially complements the first of our intentions, the whole is greater than the part. The simile of the "polyhedron" model in which "all partialities" converge but "retain their originality" can be useful.

3. The search for consensus and progress in a pluralism lived not as a threat but as wealth. Promoting and achieving a new pact within the civil society of Catalonia, achieving emotional and rational "reintegration" of the relevant minority made up between $25 \%$ and $30 \%$ of citizens, without ever having pro-independence positions, has increased by $20 \%$. Clearly pro-independence (and therefore secessionists) have stably defended this position without success, a position otherwise legitimate like others, provided that they defend themselves without violence or coercion, although it would not be ours. This scenario, where we must work on one part: confidence in the return and another part: society to configure $70-80 \%$ of the population who would favor either the compound State unit, its current autonomous form, or whether in the form that we propose as a federal compound state. There will always be a residual pro-independence of a maximum of $20 \%$, and another remaining small unit-centralizer: the purpose would be that the sum of both does not reach $30 \%$. Promoting progress in cultural pluralism and respect for multilingualism in the rest of Spain would be part of the expansion of consensus. ${ }^{23}$

\footnotetext{
${ }^{23}$ In any case, for the clarity and loyalty of all actors in this process, it would be advisable to include a neutral "protocol" for a possible approach to the issue of independence of a territory, which could be formulated from the STC 42/2014 on the "political subject" and the ability of the State to delegate to the Government - what is "a State" - the realization of a non-binding consult. According to the judgment of the TC regarding references to the "right to decide", there should be a constitutional interpretation, given that they do not proclaim as an independent character, or directly linked to the principle, first on the declaration of sovereignty of the people of Catalonia, but that they be included in the initial part of the Declaration (directly related to the initiation of a "process") and different principles of the Declaration (second, third, seventh and ninth, second paragraph). These principles, as we shall see, are suitable to the Constitution [the script is from the RFS, not the original] and give direction to the interpretation that " the citizens of Catalonia's right to decide" appears not proclaimed as a manifestation of a right to self-determination, unrecognized by the
}

\begin{tabular}{l|c} 
Página & $\begin{array}{c}\text { España y Cataluña: la reconstrucción de un pacto - v5-jmm - edito RFS } 71 \text { (2016/1) no 281· 14 de septiembre de } \\
15\end{array}$ \\
\hline
\end{tabular}


4. The European horizon may be the best framework to advance the solution of the Catalan Question, in the short and medium term. This would not be so much a final or apodictic solution, but a progressive and constructive solution of permanent and growing transfer of "sovereignty" to the EU, with adequate intellection of the dual principle (two-directional: up-down) of subsidiarity (possible recovery or "devolution" of powers). A well understood and interpreted subsidiarity from the principles of proportionality and attribution, under the Treaty of Lisbon 2009, art. 5, could offer an essential interpretive key to the development of sovereign relations. We could recover, think about and propose this federalism from the cumulated moral heritage of the federal European movement (Liberals, Social Democrats, Christian Democrats, French Republicans, etc.)

5. Finally, do the work for the cultural and moral hegemony from an inclusive and pluralistic vision in the mainstream media (social media, social networking, churches, universities, sport, business confederations, unions). In the first place it requires, together with the creation of areas of trust, to break the "spiral of silence" in the Spains about our plural, diverse, plurilinguistic society, and "unmask" other biased or false views about an exploited, oppressed, "dependent" Catalonia (which it effectively yet irrationally establishes the fallacy of the "right to decide") or the lack of solidarity and self-absorbed Catalonia, or the backward and intolerant whole of Spain, and thus change simplistic mindsets.

5.2. We agree to: a constitutional revision for a comprehensive Federal State and therefore asymmetric

Together with the pre-political pact between all citizens of Catalonia and among the citizens of Spain and Catalonia, when the time comes, which will not be immediately, we propose a constitutional revision.

Constitution, or as an attribution of sovereignty unrecognized by it, but as a political aspiration which can only be reached through a process adjusted to constitutional legality with respect for the principles of "democratic legitimacy", "pluralism", and "legality", specifically in the Declaration closely related to the "right to decide". // It is therefore a constitutional interpretation of references to "the right to decide for the citizens of Catalonia" and as such it must be stated in the judgment (Legal basis 3-b)

\begin{tabular}{l|l} 
Página & $\begin{array}{c}\text { España y Cataluña: la reconstrucción de un pacto - v5-jmm - edito RFS } 71(2016 / 1) \text { no } 281 \cdot 14 \text { de septiembre de } \\
16\end{array}$ \\
\hline
\end{tabular}


The following could be a central position of a proposal for a constitutional revision ${ }^{24}$. From a political conception of Spain as a nation and as compound State, where there are several historic national communities, including Catalonia, the federal State resulting from the constitutional revision would be a State:

1. Asymmetrical federal state as a mode or way of articulating diversity in common, especially on issues of cultural identity and linguistic protection. Which means recognizing the social and cultural reality: the existence of a common Spain, but plural and diverse. At the same time, it could help avoid a centrifuge and unequal dynamics derived from a feeling of not being recognized in their uniqueness. From this perspective, the following could be of interest:

a) Expressly mentioning of the autonomous communities, at least from what was initially established in the EC: the historical and regional, the "referendums" (Catalonia, the Basque Country, Galicia) which had access to autonomy through EC 151 (Andalusia), the territorially special (the Canary Islands) and the autonomous cities. All this as a way of voicing recognition of such diversity in the Constitution.

b) The establishment of explicit and assessed skills in an "ironclad" sense for each of the levels of government (European, Spanish, state, local and others such as the insular, provincial, etc.), but not opposed to mobile "recoveries" (two-directional subsidiarity principle: up / down, as recognized by the Treaty of Lisbon).

c) The beginning of a thorough and serene debate around the way of integrating judicial power and the administration of justice within the framework of a federal State like the one proposed. Please note, in this regard, some of the integral institutions of the judiciary have been contested in the process of the Catalan question since the adoption of the Statute of Mirabet (2006). As there is an executive and a legislative power with specific competences in each Federal State, the existence of two levels of power and the administration of justice for the federation and each of the states is articulated. Questions of the administration of justice should be thought thoroughly in a compound State.

\footnotetext{
${ }^{24}$ The EC 168.1 states: "When the review was proposed (italics RFS) the whole or a part of the Constitution affects the preliminary title, the second chapter, first section of Title I or Title II."
} 
d) Progress in the financial autonomy of the regions, specifically in Catalonia. It seems advisable that the system leans toward providing more resources available to the autonomous communities, diversely establishing the principle of financial autonomy with the principle of territorial solidarity (EC 156.1), for what could be a good path toward deepening the principle that orders public spending with regard to the available "per capita" funding ("per capita" ordinality).

e) The integration of territorial diversity in decision-making processes that establish and regulate the ordinary. Along this line, we might rethink the meaning and functions of the Senate as a chamber of territorial representation. The autonomous communities -such as the States they are- must participate with more intensity, loyalty, and involvement in politics and legislation that affect the entire state.

2. Comprehensive Federal State that guarantees the ordinary, unites citizens and autonomous regions in the same compound state, a promoter and protector of a way of articulating the common with the singular. From this perspective it should be:

a) A guarantor of legal, real, and effective equality (EC 1.1; 9.2; 14) of every citizen, with regard to the legal and social state.

b) Defender and active promoter of a genuine constitutional loyalty of citizens and all public authorities, beginning with "post-national constitutional patriotism."

c) A state that values, protects and helps explain what unites us since some time ago, through:

a. an educational system with a "core curriculum" in primary and secondary education

b. an agreed common citizenship education

c. a "negotiated" vision of history and complex identities but not in last place

d. an explicit recognition and legal protection of curricular diversity

e. in one word, an integrated curriculum, which can precisely be common because it integrates and recognizes diversity (based on the model of the "comprehensive school", although understanding the expression in a somewhat different sense). 
We propose a new social and cultural pact (ideological, emotional, and axiological) in the pre-political arena among the citizens of Catalonia, and between them and the citizens of Spain. This pact will allow for a new political pact that is subjected to a referendum of constitutional review involving all Spaniards.

One of the greatest Catalan journalists of the twentieth century, Agusti Calvet, known as "Gaziel", wrote in April 1923, concerning the relationship between Spain and Catalonia: One and the same thing: inability, incomprehension. Two different, but twin samples of a single case of "iberismo" (Iberian federalism) ${ }^{25}$. We believe there are other ways than incomprehension and inability, but we have to look for them and build them. This is why we have written this editorial. Since it has never been said that the only option is to separate or destroy a centuries-old relationship, we want to build on the perspective of the common good of the emerging social philosophy of the ordinary, a new covenant. We want to build and we will build.

Following the inspiration of the ancient medieval rule from Justinian tradition, "quod omnes tangit ab omnibus approbari debet" (What touches all must be approved ) ${ }^{26}$, we believe that the pursuit and promotion of the common good with an integrative speech of each and everyone, can be key to finding a solution to the Catalan question, knowing that the democratic will that expresses the will of everyone (omnes) is a much more fruitful possibility than the confrontation between those who hold alleged expressions of Rousseau's volonté générale (general will). This is not the will of each and everyone, will is attentive to the common good, a totalizing and collective will, unaware of people and their communities. The pact (foedus) itself can substantiate and guarantee the exercise of an integrating speech at the service of the common good.

\footnotetext{
${ }^{25}$ This article was included in a later book with an expressive title, Tot s'ha perdut (All is Lost), written after the events of October 1934 with the revolt of the authorities of the Government, the short-lived independence of just a few hours and overreaction, exerted only by force, by the central republican conservative government.

26 "What concerns everyone, must be approved by everyone." Cited regarding the Hispanic kingdoms, Maravall, J. A. MARAVALL (1973) "La corriente democrática medieval en España y la fórmula "quod omnes tangit ("The democratic current in medieval Spain and the formula "What touches") in History Studies of Spanish Thought. Middle Ages, Madrid, Hispanic Culture, I, 175-190 and with respect to ecclesiastical history, cited Y. CONGAR (1958) "Quod omnes tangit, ab omnibus tractari et approbari debet" (Anything anyone does, must be done and approved by all): Revue historique de droit français et étranger (Historical review of French and foreign law) 36 (4), 210-259. References in I. MERELLO (2005) "La máxima "Quod omnes tangit" (The maxim "He who does it"). An approach to the status of the topic: Revista de Estudios Histórico-Jurídicos (Journal of Judicial-Historical Studies) 27, 163-175.
}

\begin{tabular}{l|c} 
Página & $\begin{array}{c}\text { España y Cataluña: la reconstrucción de un pacto - v5-jmm - edito RFS } 71 \text { (2016/1) № 281· 14 de septiembre de } \\
201611: 25\end{array}$ \\
\cline { 2 - 2 } &
\end{tabular}


In constructing a democracy at the service of all, it cannot be guaranteed simply through structures alone, however good they are. Even the best structures only work when the community is animated by convictions capable of motivating people to assent freely to the social order. Freedom requires conviction; conviction does not exist on its own. If there were structures which could irrevocably guarantee a determined-good-state of the world, man's freedom would be denied, so that, ultimately, they would not be considered good structures. ${ }^{27}$

This participation and deliberation must be accompanied, as radically necessary conditions for a serious and continuing education institutionalism, for legality and a democracy of rules: this is an essential democratic key. Democratic deliberation is at odds with the spontaneity and emotionalism, and possible populist drifts. Democratic deliberation promotes and educates in democratic public virtues, both for reflection and for action-commitment.

Deliberative intensification of the people in the democratic reconstruction for the service of the common good and everyone's ethical commitment through the exercise of civic virtues can contribute to the recovery of joint projects. This may be an appropriate way to promote everything the common good requires. This may be the way to rebuild a democracy at the service of everyone, never just a system serving only private interests. This is the service of the common good that we propose, as the Second Vatican Council openly proclaimed half a century ago:

Promote all that is required for the common good, never putting their own interests to the common $\operatorname{good}^{28}$

Building a new relationship and a new political pact from a renewed social and cultural consensus of pre-political character is possible. The citizens of Catalonia can and must build this new relationship among the Catalan citizens themselves. Among them and the citizens of the whole of Spain it is possible to reconstruct the "pacting" relationship. In the perspective of a united, coherent, strong and stable Europe, federal asymmetries that are part of the original core of the European integration project should not hinder progress of a growing and closer unity. It is also possible

\footnotetext{
27 Benedict XVI (2007) Encíclica Spe salvi sobre la esperanza cristiana (Encyclical Spe Salvi on Christian hope), 30 November 2007, no. 24.

${ }^{28}$ Second Vatican Council (1965) Pastoral Constitution Gaudium et Spes on the Church in the Modern World no. 75.
} 
to think of a Spain able to integrate into the ordinary what is different, a united, plural, and diverse Spain. Solidarity between the regions and equality among all citizens from the federal pact should include recognition of the differential.

Therefore, we propose to start with a plan of pragmatic arrangements of interests and demands that give rise to a new social and cultural pact between Catalonia and Spain as a whole, giving way to a new political pact submitted to referendum for constitutional review in order to make an integrative speech possible. That is our proposal.

The English version of the editorial, Spain and Catalonia, rebuilding PACT is available at www.revistadefomentosocial.es as of the appearance of this issue in print. Access to the text in Castilian (Spanish) is free as of now at the same web address. 